\title{
Approaching Retirement After a Working Life in Poverty
}

\author{
Jon Swain ${ }^{1}$ (D) J. D. Carpentieri ${ }^{1} \cdot$ Samantha Parsons $^{1} \cdot$ Alissa Goodman $^{1}$
}

Received: 18 May 2020 / Accepted: 5 November 2020/Published online: 04 December 2020

(C) The Author(s) 2020

\begin{abstract}
This paper uses a life course perspective to explore and understand how an individual's experiences over their lifetime contribute to the formation of a growing consciousness about their impending retirement. The fieldwork took place in 2016 and was part of a wider mixed methods study about retirement in the UK, which used data from the 1958 birth cohort study (also known as the National Child Development Study). The paper focuses on the qualitative dimension of the study and uses in-depth case studies of four people approaching 60 to consider, in particular, the effects of health, financial resources and employment history on their views on retiring, including the anticipated timing of their exit from the labour market. All four were purposively chosen because they had experienced low pay or poverty during their lifetime and were employed in relatively low paid jobs. State Pension Ages (SPAs) are on the rise in many countries, including the UK, and the authors maintain that it is important to study the working poor, who, even though are more likely to continue working until SPA, are more prone to suffer from poor health, and less likely to be able to put savings aside for their retirement.
\end{abstract}

Keywords Retirement $\cdot$ Attitudes, expectations $\cdot$ Life course $\cdot$ Agency $\cdot$ Case studies

Jon Swain

j.swain@ucl.ac.uk

J. D. Carpentieri

j.carpentieri@ucl.ac.uk

Samantha Parsons

s.parsons@ucl.ac.uk

Alissa Goodman

a.goodman@ucl.ac.uk

1 Institute of Education, University College London, 20 Bedford Way, London WC1H0AL, UK 


\section{Introduction}

The institution or concept of retirement is looking increasingly outdated (Evans et al. 2013), and has become more complex, unpredictable, fragmented, and less easy to define (Vickerstaff and Cox 2005). In this paper, we explore how individuals' experiences throughout the life course contribute to the formation of a growing, or 'existing', consciousness (Karp1989, p. 751; see, also Bingham 2019) about making the transition to retirement, focusing on four people living and working in England who were approaching 60. Each has experienced low pay and poverty during their lifetime, and had been, or were, employed in relatively low income jobs: in other words, they came from the group of disadvantaged workers known as 'the working poor'. According to the Institute for Fiscal Studies (IFS) the proportion of people in the UK who are working and in poverty (judged by having an income below $60 \%$ of the national median) has risen sharply from $13 \%$ in $1994-95$ to $18 \%$ in 2017 , meaning that about eight million people living in working households are in relative poverty (Bourquin et al. 2019).

Born in 1958, the individuals in this study are also part of the late 'Baby Boomer' generation, and with State Pension Ages (SPAs) rising in the UK to 66, we argue they are a particularly important group to study because, even though they are more likely to remain in work until SPA (Author reference anonymised for review), they are more prone to poor health and are less likely to be able to accrue sufficient financial capital for their retirement. They are a central concern to policy makers, pension programmes and researchers working in the fields of gerontology, and associated health studies and labour economics.

Retirement 'has been recently been reinvented as a time of transition to a new life, rather than simply the end of an old one' (Hockey and James 2003, p. 102). Although it is increasingly understood in terms of positive productivity (Johnson and Mutchler 2014) and more 'active ageing' (Calasanti and Repetti 2018; Zaidi and Howse 2017), which provide opportunities to enjoy a dynamic 'third age' (Formosa 2014; Laslett 1989), Foster (2018) points out that much of the emphasis on active ageing has been on government attempts to increase productivity and efforts to try and get people to work longer. Even around 20 years ago, Scales and Scase (2000) observed a polarisation emerging between affluent early retirees (e.g., from professional and managerial groups) and disadvantaged older workers, many of whom are working class, and, because of the raising of SPA, are often forced to continue in low-paid employment through financial necessity, despite the wish from many to retire. Life is also becoming particularly harsh for women, who, until 2011, were expecting to obtain their state pension at 60 , in 2018 , but who now have had to adjust to the fact that they won't be receiving this money until 2024. Although there is no health insurance in the UK for the National Health Service (NHS), and people are still entitled to free access, state benefits such as Disability Living Allowance or Personal Independence Payment stop at SPA.

In order to understand the meaning of retirement we need to realise that, for many people, retirement is a process and feelings are formulated over many years (Atchley 1982): essentially, though, it can be divided into three main periods: pre-retirement, the retirement transition and post-retirement. Around 30 years later, Feldman and Beehr (2011) also proposed a three-phase model in the decision-making process to retire: 
Phase 1 is Imagining the Future: The Possibility of a Future Retirement; Phase 2 is Assessing the Past: Deciding the Time to Let Go; while Phase 3 is Transitioning into Retirement: Putting Plans into Action. The four individuals we focus on are located in Phase 1, 8 years before reaching SPA, and the particular focus in this paper is on the timing and nature of these individuals' expected retirement, their attitudes, and the plans they have (or have not) made for this approaching event.

Following the introduction, the paper provides a brief résumé of the surrounding recent literature about retirement; outlines the theoretical orientation we are drawing on; specifies information about the methodology; and presents background information about each of the four participants in the form of a series of vignettes. The second half of the paper shows how we make sense of their interview data using our theoretical understandings.

\section{Literature Review}

Much of the literature on the subject of retirement is about people who are either about to retire, or who have already retired, and relatively few studies have explored the attitudes and expectations of late baby boomers. (See Genoe et al. (2018) and Kojola and Moen (2016) for researchers who have studied this age group.) Moreover, many studies focus on well-educated, career professionals, and there are fewer about lower income earners. (See, for example, Author reference anonymised for review; Hamilton and Hamilton 2006, whose research includes this group.)

In the last 5 years there have been a number of important academic studies about retirement from Australia, Europe, the UK and US, which have covered a wide range of themes, including some that we are interested in exploring further in this paper. For example: the motivations for retiring (Du Prel et al. 2019); making plans and preparing for retirement (Denier et al. 2017; Earl et al. 2015; Hall and Keohane 2016; Heraty and McCarthy 2015; Moffatt and Heaven 2017; Principi et al. 2018; Schmidt-Hertha and Rees 2017; Vickerstaff and Cox 2005); expectations of retirement (Beier et al. 2018; Smeaton et al. 2017; Solem et al. 2016); women's perceptions of retirement (Sheppard and Stanford 2019; Sherry et al. 2017); retirement transitions for baby boomers (Gettings 2018; Genoe et al. 2018; Kojola and Moen 2016); the timing of retirement (Steiber and Kohli 2017), including the impact of poor health, physical limitations and cognitive capability (Stafford et al. 2017); the relationship between retirement and poor educational qualifications (Foster 2018; König et al. 2019); the relationship between retirement and the lack of pension income (Foster 2018; Nolan and Barrett 2019); and the influence of work history, occupation and unemployment on retirement across the life course (Dingemans and Mohring 2019; Leinonen et al. 2018; Ponomarenko et al. 2019).

Although the majority of these studies have employed quantitative methodologies, and drawn on large longitudinal data bases, other research has used qualitative designs (generally in the form of interviews) to enable researchers to explore individuals' expectations about future retirement decisions in greater depth (see, for example, Furunes et al. (2015); Genoe et al. (2018); Keogh and Roan (2016); Kojola and Moen (2016); Moffatt and Heaven (2017); Principi et al. (2018); Schmidt-Hertha and Rees (2017); Smeaton et al. (2017); Taneva et al. (2016). However, none of these studies has 
used in depth case studies to exemplify the lived experiences of particular lives concerning issues around retirement.

\section{Theoretical Orientation: A Life Course Perspective}

Longitudinal data are particularly suited to life course research (Heinz and Kruger 2001), but although the majority of studies using this perspective continue to apply quantitative methodologies, authors such as Heinz (2017) and Hollstein (2018) have written about the benefits of using qualitative, biographical narrative methodologies, that emphasise the meanings people make of their own lives in and across time.

Despite there being no unified theory of the life course, it shares four common perspectives (Elder 1994; Elder et al. 2003; Heinz et al. 2009; Settersten 2003;): (i) lives follow trajectories that are located in a specific historical time and place; (ii) the timing of key events and transitions vary and affect their meanings and consequences; (iii) lives are socially linked and interdependent with others, and, (iv) although they live and operate within structural constraints, people are able to exercise agency.

The life course refers to the interweaving of a series of age-graded, longitudinal 'trajectories', or domains, such as education, employment, that are subject to changing conditions and future options, and to short term 'transitions', ranging from leaving school, and including retirement (Elder 1994). In this paper we focus particularly on the trajectory of employment, which is viewed as a central organising principle of the life course (Henretta 2003). While trajectories are long-term identifiable pathways, or patterns of stability and change, transitions are discrete and bounded in duration and refer to changes in status; they are embedded in trajectories and act as life course markers.

Similar to transitions are 'key events' or 'turning points' (Elder et al. 2003; Verd and López 2011), although not all transitions necessarily involve these. Whereas transitions may be viewed as 'biographical milestones', turning points are more like 'biographical disruptions' (Verd and López 2011), or 'discontinuities' (Settersten 2003), which can affect a trajectory (e.g., a work trajectory may be delayed by child rearing). They do not always have to be single events but can also be the beginning of a more gradual process, such as retirement. Although turning points do not always mark the beginning of a new transitional direction or epoch (such as beginning a new career at work or retiring), they can still lead to moments of substantial change that may require a reorientation and re-organisation of one's life. They can be positive (such as gaining a new job or finding a partner) or negative (such as losing a job or experiencing a serious health issue). Because lives are lived interdependently, these events will often involve changes for other people as well. It is also important to remember that the personal implications of a key event/turning point, depend on an individual's personal characteristics and resources they are able to draw on, and this will affect the degree of agency they are able to exercise. The extent to which a turning point leads to a loss of personal control is also contingent on the amount of preparation people have made, as well as the type and gravity of the change (Elder 1994). Along with key events are key people who individuals meet and who have a profound influence on their lives. These will include family members and partners and employers.

As we have mentioned above, one of the fundamental principles of the life course framework has been that individuals are capable of exercising agency and shaping their 
own biography (Elder and Giele 2009) Although agency can be a difficult concept to both define, we are using the term to mean the capacity and degree to which individuals are able to actively 'exercise control' (Bandura 2001, p.11) over events and situations; we also recognise that there is an interdependence of the past, present and future in the life course, and the decisions people make are affected by each of them (Heinz et al. 2009). Any understanding of human agency also needs to recognise that the life course is affected by multiple influences such as macroeconomic conditions, institutional structures such as socio-economic status, social class, gender, ethnicity, as well as acquired attributes, habits, dispositions, and individual resources such as ability and aspirations (Evans and Biasin 2017). Health is also another important factor (Karp 1989), which is further complicated because the health of a spouse, or of a significant other, may also come into play (Carpentieri and Elliott 2014).

\section{Methodology}

The fieldwork for this paper was part of a wider mixed methods study about retirement (Author reference anonymised for review), which was funded by the Joseph Rowntree Foundation, and used data from the British birth cohort study (also known as the National Child Development Study, or NCDS). Following the lives of 18,558 people born in a single week of 1958, the most recent quantitative sweep was in 2013, with 9137 individuals, aged 55; the qualitative data in the study were based on interviews conducted in 2016 with a subset of these individuals, who were 58 at the time.

The primary aim of the qualitative component in (Author reference anonymised for review) study was to explore cohort members' attitudes to, expectations of, and plans for, retirement, and the factors that have shaped these. The fieldwork involved in-depth interviews with 36 individuals who were purposively sampled based on findings from the quantitative analysis. All interviewees were selected because they were in the bottom quintile of household income from within the cohort at the age of 50 and 55. Twenty-five were in work at the time of the fieldwork, while 11 were chosen because they were out of the labour market. The sample was geographically divided: 19 interviewees lived in the South East of England, including London, 17 lived in the North of England (North West, North East, and Yorkshire and Humberside), and the gender split was 50-50.

Three researchers telephoned a number of potential participants who fulfilled the above criteria to arrange face-to-face interviews in their home. Interviews were semistructured and the schedule was divided into eight areas of enquiry: in addition to asking questions about retirement, the interviews also gathered demographic information and data on their general health, employment history, feelings about growing older, leisure interests, caring responsibilities, and their financial situation. Interviews lasted around an hour and a half and were all digitally recorded and transcribed. Interviewees have been given pseudonyms, and any identifying features of their stories have been suitably anonymised.

We used biographical interviews (Fischer-Rosenthal 2000), which assume that the link between structure and individuals can only be understood by analysing a person's development over the life course, and thus an analysis of the individual cases is emphasised. This approach is strongly linked to Schutz's (1970) theory of social 
phenomenology, which is 'an interpretive theory of social action that explores the subjective experience within the taken-for-granted, "common-sense" world of the daily life of individuals' (Fereday and Muir-Cochrane 2006, p. 81). The assumption underpinning the theory is that people are able to attribute meanings to situations and make a coherent series of evaluations of their everyday life.

To make sense of interview data, researchers employed a type of thematic analysis called a hybrid approach (Swain 2018), which combines deductive and inductive philosophical approaches and creates a set of a priori (or pre-empirical) codes that are derived from the research aims and interview questions, and a series a posteriori (post-empirical) codes that are generated from the data themselves. This means that the a priori codes were already known before fieldwork began, and, for example, attitudes to retirement, health, employment history, were themes explored in the interview schedule. It was much more difficult to anticipate the a posteriori codes which began to form as researchers read through the interviews transcripts. Some of these included, enjoyment of work, family support, depression and so on.

We decided to focus on a limited number of interviewees in order to uncover the lived experiences and lived realities of their lives and pursue greater in-depth analysis of their narratives than would have been possible with a larger number. In choosing these cases we selected relatively distinct (and where possible, contrasting) 'types'e.g., two men and two women; two in good health, one in 'fair' health, and one in poor health; two who were home owners and two who were in rented accommodation; all four were white British, in work, one lived in the north and three in the south, and only one was living with a partner at the time of interview. One expected to transition to working part-time, two, who, because of financial constraints, were anticipating working full-time till, or past, SPA, and one who intended to keep working, even though they were relatively financially secure. The four interviewees we have selected are not chosen for their representativeness, and we are also aware that this approach can never fully capture the heterogeneity of the interviewees' responses from the sample of 36 , yet alone the stories of those from the thousands in the wider quantitative survey who were asked questions about retirement. Nevertheless, we believe that each of these four people represents a distinct and particular story or type that is typically found amongst working class people of this age who have also experienced poverty at some recent point in their lives. We are regarding the four stories as being 'telling' cases (Candappa 2017), or 'revelatory' cases (Liebow 1967), which are able to uncover a series of key aspects and issues, which, we argue, are likely to have a profound effect on the preretirement process and generate hypotheses as researchers gain access into people's daily lives.

\section{Four Case Studies}

We begin this section by introducing the four interviewees as a series of vignettes.

1. A woman in good health, with few financial resources, who needs to keep on working fulltime but is happy to do so

2. A man in moderate health, with sufficient financial resources, which give him a greater choice of how and when to retire 
3. A woman with poor health, with few financial resources, who needs to keep on working full-time but is reluctant to do so

4. A man in good health, with reasonable financial security, who wants to work for as long as possible

\section{Gillian}

At the time of the interview Gillian was optimistic and seemed in good health. She was living with her 24-year-old daughter (who was independent and working) in private rented accommodation on the outskirts of London. She has moved nine times since her daughter was born and this makes her feel insecure: 'I feel a bit like a nomad and I've learnt to feel insecure so I've got used to the fact that I could be moved out at any time.' She regards never having enough money to buy her own property as her biggest financial regret. Gillian had lived with a partner (and the father of her child) for a number of years but was currently single and no longer saw him. Her mother was alive and in good health, and Gillian has no family caring responsibilities.

She left school at 17 without any higher grade academic qualifications and trained to be a hairdresser. She has had a series of low skill, low paid jobs, but has always fallen back on hairdressing in times of need and uses it to supplement her income. Money is currently tight, and because both she and her daughter work, she does not receive any state benefits. She has four jobs and describes herself as 'Jack of all trades'. Her main job is working for a private company at the local swimming pool where she doubles up as receptionist and occasional swimming coach, although she is not fully qualified. Her other two sources of income come from caring for an elderly woman for 2 or $3 \mathrm{~h}$ a week, and from her hairdressing, which she carries out in people's homes for a few regular clients.

Gillian presented herself as an active person who dislikes any form of office based employment. She said her parents had tried to inculcate a culture of saving but low pay over her life has made this difficult. She has taken out a workplace pension, but this is only 3 years ago, and she also has a few shares. Her main source of money in the future is likely to come from her mother's house in which she has a quarter share. She has many close friends who she regularly socialises with, and this, with her low rate of pay, appears to be a further reason why she is unable to put much money aside. As she works so hard she feels she has earned the right to enjoy herself. She has few regrets and declared, 'I love living my life and I do; I work hard but I play hard'. Although she does not have any high material expectations she is generally content with her life:

I've got everything that should be construed as a reasonable life. I've got a roof, I've got a job, I've got money coming in, my bills are paid, I've got a daughter, I've got my health, my mum, my family.

She is enjoying her work, as it provides variety, and she gains satisfaction from helping people; she also admits that she would miss the routine and social interaction if she were to stop. Nevertheless, she still regards work as a means to an end and feels that retirement is quite far off. She intends working till 66, and she has not seriously begun to envisage what she would do when she reaches SPA. When asked whether she has 
made any plans for her retirement, she replied that 'I'd expect the majority of people do .... but I'll be one that won't: I just take every day as it comes'. She wants to have time to enjoy life while she is still physically and mentally able but says that she also wants to keep her options flexible, and that she would not rule out working part-time into her 70 s, depending on her needs, and if she found the job was suitably satisfying.

Gillian's main worry for her life beyond SPA is financial - will she have enough money to support her current life style? - and, at the time, she was not overly concerned about her health. Presenting herself as a determined character, she thinks that, if necessary, she could survive on the amount from the State Pension, as long as her rent is paid. She has experienced many tough times in her life before and therefore would know how to make adjustments.

\section{Ian}

Although Ian has lived an eventful life, which has included some very difficult times, he has shown a resilience to overcome adversity, and, at the time of the interview, was cheerful and seemingly content with life. He is living alone in a rented ex-council house in a northern city, and although he does not have a large network of friends, he is very much a 'family' man and keeps in regular touch with his two sisters, two grown up children and his grandchildren: 'we're still a close knit family which I've always valued, family values - they're the most meaningful thing in my life'. His health is 'fair' although he is taking numerous medications. He had experienced a torrid time around the early part of the century: his father died in 2000, his wife 2 years afterwards, and then, later in the same year, he was made redundant. The prospect of bringing up his two teenage children was daunting, and he became depressed and sought treatment. He did not want his children to come home from school and be alone, and so decided not to look for another job for a few years. In some ways, he came to regard losing his job as a blessing because his domestic situation began to improve: his father's death enabled his mother to come and live with him and his family and, in effect, become a surrogate mother to his children.

He left school at 16 with poor qualifications and has only had two main jobs: a steel worker for 27 years, and a bus driver since 2004, which he enjoys far more than his job in the steel mill. His main concern about getting older is further deterioration in his health, and he had recently taken advice from his sister, who was working in the financial sector, and who told him it was better for him to take his work-based pension when he was relatively healthy and able to enjoy life, rather than risk waiting till 66 when his health might worsen.

He therefore took his steel pension at the first available opportunity, in early 2016. He has also signed up for a pension scheme in the bus company and feels he will have enough money for a comfortable retirement. He recounted that the decision to opt into the pension scheme when he was younger was one of the best decisions he had ever made. He has few material aspirations or expectations, and as long as he is able to pay his bills and rent, he is content.

Ian has begun to think about retiring from the bus company and giving up paid labour altogether, but he enjoys his job and is planning to keep working till at least 66, and possibly beyond. He thinks he might decide to work into his $70 \mathrm{~s}$, if he feels right about it, and he confessed that he would particularly miss the routine if he were to stop 
altogether. He would prefer to begin working part-time - an option he can afford, and one which would allow him more free time for activities such as visiting his grandchildren. He knew of other bus drivers who were job-sharing, and so believed this to be at least a feasible, if not certain, possibility.

\section{Belinda}

Belinda was living in an outer London suburb and, although at the time she was interviewed she appeared confident and assured, she has faced challenges in life. She had experienced a nasty divorce a few years ago, and although she currently had a partner, she lives alone in a small house, although it was not yet paid for. Her two children are grown up and independent, and her father, who was in his mid-80s, was in good health.

She left school at 18 but did not gain any higher level academic qualifications. A former chef, she is now working as a teaching assistant (TA) in a primary school, a job she enjoys but which she is finding physically and emotionally demanding. She also teaches gymnastics on 2 days a week. She enjoys both her jobs and feels she would miss several aspects of her work: 'I'd miss helping kids to achieve something... I'd miss my friends... the social interaction that you get.'

For most of her adult life, Belinda has been in excellent physical condition, participating in a range of sports, and at school she runs several sport-focused clubs. However, she had recently suffered from a debilitating hip problem that has greatly reduced her mobility, making it difficult to walk and impossible to carry even light items of shopping, which is causing her to miss substantial periods of work. This most recent period of her life has 'been an absolute nightmare,' she confessed; 'it's frightened me, the last seven months, it's frightened me... not being able to do things for myself, not being able to look after myself as much as I want to.'

She is worried about her future, particularly the impact of her health on her ability to work and this has made her a little depressed. Teaching is a physically demanding job, she said - 'You're up, down, up, down' - and her recent difficulties have given her a foreshadowing of the ways in which health problems may make it difficult to continue working. One potential solution, she suggested, was transitioning to part-time work, which might enable her to work to a later age; it would also allow her more time to pursue a range of leisure interests. However, she admits that she would struggle to get by on the reduced income and so, for the moment, it is financially unrealistic.

Describing her life, she feels that she is just getting by on her full-time salary and would not be able to survive on part-time pay. Nor does she have access to other sources of income: while her home was almost fully paid for, she still owed her exhusband money for the house; she has no savings and only a small workplace pension. Due to several years of being out of the labour market and engaging in part-time working when her children were young, she expects to receive only a small state pension. 'I would have preferred to have been putting more money away for my retirement,' she said, but she was raising two children on her own after escaping an abusive relationship.

One option she has is to move in with her new partner, who has recently retired. However, she confessed that: 
One of the reasons I divorced was because I had no independence, I was seen as a possession, I had no money of my own, and I will never go back to having that, to rely on somebody else to give me money for anything, I want to be on my own, so I need to work or be able to provide for myself.

Despite her financial anxieties, her main worry is her 'health more... because it's not important having lots of money if you can't actually do things'. She feels that as long as she can remain at least moderately healthy, she will find a way to enjoy her eventual retirement, even in difficult financial circumstances: 'I'll find something to do; it costs nothing to go out for a walk, providing you can.' In the meantime, however, she is continuing to face the challenge of balancing health, work and financial necessity. Retirement, for her, is quite far away, and she hasn't made any plans because, I've learnt that things don't always go to plan; you don't know what's around the corner'.

\section{Monty}

Monty is a self-employed musician - a guitarist - who was living in a small town in the south of England, and he came across as confident, relaxed and self-contained. Apart from some food allegories, he was in good health and, at the time of the interview, he professed being very satisfied with his life.

Life is very good at the moment, I walk down the street sometimes and I just thank my lucky stars.

He did well at school and went to university to read English. He's had a very varied and interesting working life, which has included careers as a teacher in a private school, and then as a self-employed DJ, film-maker and song writer. Although he stressed his working class roots he now regards himself as being middle class, with middle class tastes such as an enjoyment of art, music, film and theatre. He relishes life, and, being an optimist, he is spurred on by the thought that 1 day he will make a massive hit record, gain a recording contract, and make a lot of money.

Despite his sunny disposition, he has experienced great sadness his life: his girlfriend died in her 20s from a drug overdose; he then came out as gay but then lost many friends through AIDS. Both his parents are dead; he had no caring responsibilities and, apart from his live-in partner, Michael, he now has very few close friends. Although he spoke about living relatively frugally, the flat that he was living in was spacious and nicely furnished, and, although he still had a long time to pay off his mortgage, he also owns and rents out a flat in London, which he bought in his $30 \mathrm{~s}$, using the proceeds of his DJing work.

He loves his work, playing solo, or as part of a band, in clubs and bars, and said that he has no intention of retiring, and wants to go on working for as long as he conceivably can. His main concern about growing older was his health: although it was presently good, he worried about feeling more tired and having less energy. Whilst he did not make very much money, and confessed he was not the type to save, he was less worried about his future financial situation because of the income from his London flat: My pension is really the flat in London, you know, that's all I've got. However, he also had the security of living with a partner who, at the time of the interview, had full- 
time employment in a professional capacity. However, Monty stressed that he had never asked Michael for any financial help. He had few material tastes or needs and said that he could live on relatively small amount of money.

I have spent my whole life not having any money so I kind of know when to stop spending money, you know

He regrets not setting up a pension plan or keeping up with his national insurance contributions and agreed that his best financial decision was buying his flat.

\section{Summary of the Four Case Studies}

Before we present our analytical discussion, we begin by providing a descriptive summary of the four interviewees' background circumstances, resources, feelings and views about retirement in Table 1 below.

\section{Analysis and Discussion}

In order to understand the timing and nature of retirement we need to place the transition of retirement into the wider context of trajectories in the life course and consider a set of an individual's personal experiences and circumstances. Of particular salience are (i) health (physical and mental); (ii) amount of financial capital; (iii) employment history and current working status; (iv) home ownership; (v) family composition (including children and marital/partnership status); (vi) dependents (both younger and older); (vii) level of education (and qualifications); and (vii) social networks, including key friendships. However, the three major themes, or factors, that emerged from the 36 interviews in the wider study were the first three of these themes: health, finance and work, and we therefore pay particular focus to these three.

The analysis shows how we apply some of the main paradigmatic features of the life course in order to develop our understandings about how individuals from the working poor feel, and make choices and decisions about, retirement. As so much data about transitions is either missing, or remains too speculative, the headings we use to organise our discussion are: (employment) trajectories; turning points; key people and linked lives; and agency.

\section{Employment Trajectories}

In this section we focus on the interviewees' working trajectories, as we argue their attachment to work has been a central part of, and helped to structure and organise, their lives (Henretta 2003). Two interviewees had left school before the age of 18, and three had either a few relatively low, or no, academic qualifications, which has had repercussions in their later lives, and will have in their future years of retirement. Monty is the exception, although he only used his academic qualifications in his first job as a teacher and they have had no bearing on his subsequent career choices: he has learned new skills informally as and when he has needed to. Moreover, perhaps a lack of family cultural capital and particular class-based aspirations, meant that three began their 
Table 1 Summary of the characteristics of the 25 interviewees at the time of interview

Cohabiting

Children

Physical health

Mental health

Parents alive

Owns own home

Thinking of downsizing to a smaller property

Work pattern

Enjoyment of work

Savings

Main leisure activities

Friendship networks

Caring responsibilities

Optimist or pessimist about life

Overall score of life satisfaction The average score on their feelings of life satisfaction was 7.6 out of 10 (ranging from 5.5 to 10$)$

14 were living with a partner. Of the 11 who were not, some were separated and 4 had experienced the death of their partner

22 had children. Most (14) of these were now grown up and living independently but kept in regular contact; however, 8 people had children still living in the family home. Only one child was under 18 at the time of the interview

18 assessed their physical health as good or better

22 said their mental health was good or better

Two had both parents alive; 14 had one parent and 9 had neither parent alive

19 owned (or almost owned) their home and 5 lived in rented or local authority accommodation (one lived with mother). Of the 19 homeowners, 10 had paid off their mortgage, and almost all the others only had a few years to pay.

Of the 19 homeowners, two had already moved to a smaller property and 6 thought they probably would move eventually. 11 intended to stay in their current home for the foreseeable future.

20 were working full-time and 5 part-time, or with reduced hours. There was a wide range of employment within the group. Although many had, or were still working, in low paid jobs (e.g. cleaning, retail, child-minding, caretaker, factory work), others had, or still were, working in more middle of the road professions (e.g. as civil servants, health administrators, drug rehabilitation officers, textile conservators). Five were actually self-employed (e.g. as painter and decorator, chef in own restaurant, drainage engineer, artist and landlord) and appeared on the surface to be earning a reasonable income. In the past, some had worked in heavy industry such as ship building and the steel industry

17 enjoyed most of the work they had done, or were still doing; 5 thought work was OK, while 3 disliked it

No one from the 25 said they had no savings at all and only 4 said they had only a very small amount of money put aside. 21 said they had at least some savings, in many different forms, although it is unclear of the amount of money involved. 14 said they had a workplace or private pension, two of whom had already cashed it in. However, many pensions were based on relatively low incomes, while some had only begun these schemes comparatively recently, and so the amount of money it likely to be small. Some people were also going to draw money from their partner's savings/pension etc. A minority said that they expected to inherit money from their parents' property.

The six main activities mentioned were taking physical exercise, particularly walking (11), watching general TV (10), following sport on TV (8), reading (8), using the internet, including computer games (7) and looking after pets (6).

13 said they had a network of friends, 12 had none outside their family. Out of the 13, 11 said they had a best or close friend to whom they could turn to when needed.

13 cared for no-one in particular, although some said they still cared for their children, despite them generally being grown up and independent. 7 occasionally cared for grandchildren, usually by baby-sitting, while 5 cared for an old parent, usually their mother.

16 felt they were an optimist; only 2 saw themselves as a pessimist; 4 were undecided and 3 were not asked this question

working trajectories either, in the case of Ian, working in heavy industry, or for the two women, in relatively low skilled and low paid professions. Family traditions may have also played a part and, for instance, Ian's father and grandfather had both worked in the 
steel industry. Gillian is the only one to have worked exclusively in the private sector: she now has four jobs (two of in which she is self-employed) in order to generate a satisfactory income to cover her life style; Ian has had only two working trajectories working in the, then, state run, steel industry, and now as a bus driver - while Belinda left school early to become a chef, then became a TA and, more recently, a gymnastics instructor. Monty has had a very varied career and been mostly self-employed, including his current job. Ian is the only one to substantially benefit from a workbased pension and, although Gillian had invested in a small amount in shares and had recently begun to pay into a private scheme, the returns are likely to be negligible by the time she reaches SPA. Belinda's main job as TA is in the public sector has also given her a small work-based pension, while Monty's main and regular source of income comes from his second property.

\section{Turning Points}

We can see that all four have experienced key events and turning points that have disrupted their lives and have either had profound consequences in the succeeding years or, in the case of Belinda, have the potential to do so in the future. These events have involved relationships with key people, while the most recent turning point for Belinda is health related, and for Ian and Monty, turning points in the past have involved the mortality of a person very close to them. As we will see below, some of these turning points can have positive, as well as negative, consequences and repercussions over a longer time-span.

It is more difficult to speculate what the turning points have been for Gillian, but with the ability of hindsight, and the chance to look back over her life, it would seem that her life changed when her partner, and father of her child, left her. However, the consequences of this action did not become apparent until later, as Gillian has needed to continue to live in insecure rented accommodation and has not been able to save money. However, in some ways, it seems to have made her become more determined to succeed, be more independent, and become more content.

Ian has experienced some devastating events which became turning points. However, because of this adversity, his mother was afforded the opportunity to live with him as a replacement mother-figure and help bring up his two children; it also forced him to search for new employment and find a new career, which he finds far more fulfilling. Another turning point may come from him taking his work-based pension, which has given him greater financial stability, and given him the opportunity to consider whether he wants to reduce his hours of work, and possibly continue working beyond SPA.

Because we are able to see the consequences on Belinda's life of the divorce from her husband we can be more confident in calling it a turning point - she told us that the divorce made her become more financially autonomous and so, as with Gillian, there were some positive as well as more negative outcomes of this event. However, we would need more time to know whether meeting her new partner will become a turning point, but although she was not currently living with him, this relationship has the potential to become one. We can be more certain that Belinda's hip injury is a turning point as it has already disrupted the quality of her life to a considerable degree and has made her reappraise her own aspirations and expectations. Although she would like to have the agency to decide to work part-time the decision may be forced upon her 
because of the state of her physical health, and this might also mean that she has to work beyond 66, even though this would be physically and mentally demanding. A turning point for Monty was certainly the death of his girlfriend, after which he reappraised his sexuality and came out as gay. Buying a flat has also proved a key event and given him a steady income stream, and also allowed him to experiment and take more risks in seeking out, and trying, other working directions.

\section{Key people and linked lives}

As we suggest above, turning points often involve key people. However, it can be difficult to tell whether an individual can, or should, be judged as being a key influence in a person's life, and like turning points, we will often need time and the benefit of hindsight. Key people are also connected to the theme of linked lives. Both Gillian and Belinda spoke about having a network of close friends, or other relatives, and one or more of these may well have been, and still are, highly influential in their lives. Ian said he did not have any intimate friends but had created his life around his extended family, while Monty had his live-in partner.

There do not seem to have been any 'standout' key people for either Gillian or Belinda, although their former partners would have been key people at one stage of their lives, and their leaving had caused both to become more independent. It is easier to find key people in the life course of Ian: firstly, there was his mother, and then there has recently been his sister who, because of her job, was able to give him advice about taking his pension early. Key people in Monty's life had been his girlfriend and, currently, Michael, who also provides him with an additional financial safety net. However, we can speculate that there have been many others, such as, perhaps, the person who introduced him to, or gave him an entrance, into DJing but there was no time to uncover them during the interview.

As far as life course theories of linked lives are concerned, none of the four at the time had dependents who were old or young. Only Monty co-habited with a partner, while the other threes' children were grown up and independent. Gillian's life was currently intertwined with her daughter and it appears that Belinda's was beginning to be with her new partner.

\section{Agency}

Underpinning all of these themes is the concept of agency. If we consider the degree of agency each of these four individuals possess, and how much it is likely to affect the timing and nature of their retirement, we can see that the two men have the capacity to exercise most. The amount of potential agency each person has is affected by past and present key people and key events or turning points. For Ian, the increased stream of economic capital means that he is able to have more options, including being able to retire before SPA. Ian feels in control of his life and is working because he wants to. Monty, too, has more choices due to the reliable, albeit relatively small, income stream from his flat and, if it was necessary, from his partner. Even though Gillian enjoys working in her four jobs, she had less agency than the two men in that she is denied a choice of when to retire or to scale back her working commitments. Belinda also has less opportunities to exercise agency, or less control of her life, than Gillian or the two 
men, which was due to her debilitating hip injury and a lack of money, which means that part-time work was not a realistic option, however much she desired it. However, the degree of agency, and the repercussions, arising from this particular key event (and for the others) are affected by the resources a person is able to access (economically, socially, physically, emotionally) - which in turn is linked to her personality, habits and dispositions, which have been formed over the life course. Although Belinda has been offered by her new partner to move in with him she wishes to remain financially independent, and not be controlled as she was by her ex-husband, and thus she opts for greater personal agency at the expense of greater financial security. Her past experience of a marital relationship has affected her deeply and illustrates how people's current plans and expectations are often based on past experience and future anticipations (Heinz et al. 2009).

We can also analyse further background factors and resources that can act as either positive or negative features in these people's lives. In terms of the positive, we can see that Gillian has good health, the resources of a loving and supportive daughter and a wide network of friends, and she enjoyed her life both in and outside of work; Ian also has the resource of close family ties, he also enjoys working, and has additional financial resources; Belinda also enjoys her work, has the resource of a partner and good friends; while Monty has the personal resources of good health, a steady income, and a close partner, The negative factors are, for Gillian, her lack of money and the insecurity of living in private rented accommodation; for Ian, they are his relative poor health, but his lack of close friends seems to be overridden by his close family ties, and, unlike Gillian, his rented accommodation - from the local council - also seemed much more secure. As far as Belinda is concerned, the main two negative factors are her health and lack of economic capital, while Monty, has few factors which are obviously negative, hence his unbridled enjoyment and high level of life satisfaction.

\section{Further Issues}

Although each of the four cases represents a particular typology about approaching retirement, the narratives also highlight a number of issues and themes that, we argue, are likely to be particularly common for other people of this age from similarly disadvantaged economic backgrounds. They not only enrich our understanding but help us propose a series of hypotheses. In addition to retirement, we have categorised the themes under the headings of employment; poor qualifications; financial capital; general well-being; family and friends; health; and anxieties about the future.

Retirement As far as retirement is concerned, one of the main conclusions from the quantitative research from (Author reference anonymised for review) study was that the working poor were the most likely group to anticipate they would be working at the age of 66. This was also the case for all four interviewees but qualitative data shows it is more complex. Like most people of this age, none had not made any firm plans for retirement, and they wanted to keep their options open and assess where they were at 66. Gillian and Belinda needed to work full-time (however, reluctantly in the case of Belinda) in order to remain financially solvent, while Ian probably would also continue working as long as he could reduce his hours and continue to enjoy his work, and Monty would definitely work as long as possible, although this was contingent on his health. 
Employment Working in the state sector (whether this be as a teaching assistant or in the steel industry) generally provides workers with greater security of tenure and the opportunity to begin paying into a work-based pension (Ian, and later Belinda), preferably as early as possible, which helps their financial well-being in old age. These data confirm that low skilled jobs are more likely to be lowly paid, and many people, like Gillian and Belinda, need to have more than one job. Having said this, all four people in this study enjoyed their work: they liked the routine and structure and social aspect, but we argue that many people are prepared and happy to work up to, and often beyond SPA, if they find their job rewarding and feel they can retain some control. Some would like to reduce their hours as they approach SPA but there can be a lack of part-time work and few employers offer opportunities for job-sharing. Poor qualifications: Three of the interviews showed that early decisions in the life course, such as leaving school with poor qualifications, may have later consequences: it limits employment opportunities and is more likely to result in individuals entering manual trades or taking work which is low-skilled and low paid. However, Monty's case shows that there is not always a strong correlation between high level qualifications and employment and, apart from his first job as a teacher, Monty's were largely irrelevant to his career trajectory. Financial capital: Working in these type of jobs makes it harder to be able to consistently put savings aside, and, for Gillian and Ian, this has meant that they have had to live in rented accommodation, which is also more insecure, particularly in the private rented sector. Saving is often more difficult for women: they are more likely to have spent a greater proportion of their time outside the labour market due to childcare commitments, and also earn less over their lifetime because more tend to work in part-time employment with reduced hours. As we have seen with Ian and Monty, money also tends to give people a greater chance to exercise agency. General well-being: Although Monty's partner made his life both happier and more financially secure, life can be more difficult (particularly financially) if a person is single. However, this is not always the case and sometimes people (such as Gillian and Belinda) are more content not co-habiting. Some people are also happier after their divorce (Belinda) or after separating from their partner (Gillian). Even though the four need to live modestly, they have learned to live with few material possessions, are able organise their lives thriftily, and exist on relatively little income. As Gillian says, the most important things in life are health, a roof over one's head, food on the table, a modest income stream, and close friends, including family. Family and friends: Friendships for some are important but other people, like Ian and Monty, are much more self-contained and can be content without a close network of friends, relying, instead, on family networks or a cohabiting partner. Parents can also be very supportive: often parents' homes can provide a valuable source of income when they die, and people are lucky if their parents have this asset. Health: Good health is generally more important than money when it comes to contentment and if it deteriorates it can have a devastating repercussion on a person' life, including on their employment. This can happen very quickly, as Belinda has found out. Anxieties: Like all of the other 36 participants, these four expressed worries about their future retirement, including growing older, and as the literature confirms (Centre of Ageing Better (2015)), most of these were concerned with health or finance and sometimes both. For Gillian, it is the need to maintain a consistent financial stream and she also felt extremely vulnerable in her accommodation, which she might be asked to leave at short notice. The greatest 
concern for the two men is their physical health, particularly for Ian, even though it was not a particular issue at the time of interview, while Belinda has both physical health concerns and money worries.

\section{Conclusion}

There has been a long tradition of using biographical narrative analysis in the life course tradition (Heinz 2017; Heinz and Kruger 2001), and this paper has shown how various experiences accumulated over the life course have both provided, but also closed down, opportunities and contributed to shaping individuals' thinking, attitudes and expectations about this transition. As part of the life course paradigm, we have analysed how particular employment trajectories, significant people, and key events and turning points (which are often health or financially related), shape attitudes and decision-making processes towards and about retirement. We have also considered the role agency plays in retirement expectations, the ways in which it is enhanced or diminished by a number of personal circumstances, attitudes and dispositions formed over the life course, and the range of economic, personal, social, physical and emotional resources that each person has built up and is able to draw on.

The four cases we have presented each represent a particular typology of approaching retirement, but are also able to illustrate additional issues and themes, and have enabled us to show how wider structures of social class, gender and poverty are represented, encapsulated and demonstrated in and through these individual lives. Many of these themes are connected to money in the form of having (or not having) financial savings (e.g., from a relatively full and secure work-based pension, property ownership or lack of financial dependents), state of health (particularly physical wellbeing), and the type of employment, but we also looked at the life time effects of leaving school with poor qualifications, and the importance of family and friendships.

Although some people might regard the fact that the four participants we focused on were still 8 years away from SPA at the time of their interview, and therefore had only begun to form a growing awareness of retirement, we argue that it is important to study the retirement attitudes and expectations of individuals in their late fifties, both conceptually and practically, as this is the time when people first begin to develop a consciousness about retirement. Baby-boomers' increasing life expectancy has made them subject to close policy attention and significant pension and employment reforms, and it is particularly important to study the working poor, who, even though are more likely to continue working until SPA and beyond (Author reference anonymised for review), are more predisposed to suffer from poor health and less likely to be able to put savings aside for their retirement. These particular late boomers are also the first group of people to feel the force and implications of policy changes, such as the raising of SPA, and so, we maintain, their lives and views are particularly worthy of attention. The stories from the case studies hint at the changing nature of retirement from an earlier time where there tended to be a binary transition from full-time work to no work, to more gradual and flexible work transitions from full-time to part-time, or from parttime to less part-time before a state of no work is reached. It is no longer easy to define normative expectations of retirement, although we should not be surprised that baby 
boomers may be reinventing both retirement planning and the institution of retirement itself because, as Moen et al. (2005) point out, they have already individualised every prior phase of the life course.

Open Access This article is licensed under a Creative Commons Attribution 4.0 International License, which permits use, sharing, adaptation, distribution and reproduction in any medium or format, as long as you give appropriate credit to the original author(s) and the source, provide a link to the Creative Commons licence, and indicate if changes were made. The images or other third party material in this article are included in the article's Creative Commons licence, unless indicated otherwise in a credit line to the material. If material is not included in the article's Creative Commons licence and your intended use is not permitted by statutory regulation or exceeds the permitted use, you will need to obtain permission directly from the copyright holder. To view a copy of this licence, visit http://creativecommons.org/licenses/by/4.0/.

\section{References}

Atchley, R. C. (1982). The process of retirement: Comparing women and men. In M. Szinovacz (Ed.), Women's retirement policy implications of recent research (pp. 153-168). Beverley Hills: Sage.

Bandura, A. (2001). Social cognitive theory: An agentic perspective. Annual Review of Psychology, 52, 1-26.

Beier, M. E., Torres, J. W., \& Gilberto, J. M. (2018). Activities matter: Personality and resource determinants of activities and their effect on mental and physical well-being and retirement expectations. Work, Aging and Retirement, 49(1), 67-78. https://doi.org/10.1093/workar/waw034.

Bingham, D. (2019). Older workforces: Re-imagining later life learning. Abington: Routledge.

Bourquin, P., Cribb, J., Waters, T. and Xiaowei, X. (2019) Why has in-work poverty risen in Britain? Institute of Fiscal Studies (IFS) Working Paper W19/12. Available at https://www.ifs.org.uk/publications/14154. Accessed 2 Dec 2020.

Calasanti, T., \& Repetti, M. (2018). Swiss retirees as "active agers": A critical look at this new social role. Journal of Population Ageing, 11(1), 23-41.

Candappa, M. (2017). Case Studies. In J. Swain (Ed.), Designing research in education: Concepts and methodologies (pp. 173-192). London: Sage.

Carpentieri, J., \& Elliott, J. (2014). Understanding healthy aging using a qualitative approach: The value of narratives and individual biographies. In D. Kuh, R. Cooper, \& R. Hardy (Eds.), A life course approach to healthy ageing (pp. 118-129). Oxford: Oxford University Press Oxford.

Centre of Ageing Better. (2015). Later life in 2015: an analysis of the views and experiences of people aged over 50 and over. Retrieved from http://laterlife.ageing-better.org.uk/resources/cfab_lli_2015_ipsos_ mori_report.pdf. Accessed 18 Apr 2020.

Denier, N., Clouston, S., Richards, M., \& Hofer, S. (2017). Retirement and cognition: A life course view. Advances in Life Course Research, 31, 11-21.

Dingemans, E., \& Mohring, K. (2019). A life course perspective on working after retirement: What role does the work history play? Advances in Life Course Research, 39, 23-33.

Du Prel, J.-B., Schrettenbrunner, C., \& Hasselhorm, H. M. (2019). Vertical and horizontal social inequality and motivations for early retirement. Zietschrift fur Gerontologie und Geriatrie, 52(1), 3-13.

Earl, J. K., Bednall, T. C., \& Muratore, A. M. (2015). A matter of time: Why some people plan for retirement and others do not. Work, Aging and Retirement, 1(2), 181-189. https://doi.org/10.1093/workar/wau005.

Elder, G. (1994). Time, human agency, and social change: Perspectives on the life course. Social Psychology Quarterly, 57(1), 4-15.

Elder, G. H., \& Giele, J. Z. (Eds.). (2009). The craft of life course research. New York: Guilford Press.

Elder, G. H., Johnson, M. K., \& Crosnoe, R. (2003). The emergence and development of life course theory. In J. T. Mortimer \& M. Shanahan (Eds.), Handbook of the life course (pp. 3-19). New York: Kluwer Publishers.

Evans, K., \& Biasin, C. (2017). Exploring agency, learning and identity in women's life trajectories in United Kingdom and Italy - Exploración de la agencia, el aprendizaje y la identidad en las trayectorias de Vida de las mujeres en el Reino Unido e Italia. Revista Española de Educación Comparada, 29, 15-32.

Evans, K., Schoon, I., \& Weale, M. (2013). Can lifelong learning reshape life chances? British Journal of Educational Studies, 61(1), 25-47. 
Feldman, D. C., \& Beehr, T. (2011). A three-phase model for retirement decision making. American Psychologist, 66(3), 193-203.

Fereday, J., \& Muir-Cochrane, E. (2006). Demonstrating rigor using thematic analysis: A hybrid approach of inductive and deductive coding and theme development. International Journal of Qualitative Methods, $5(1), 80-92$.

Fischer-Rosenthal, W. (2000). Biographical work and biographical structuring in present-day societies. In P. Chamberlayne, J. Bornat, \& T. Wengraf(Eds.), The Turn to Biographical Methods in Social Science (pp. 109-125). London: Routledge.

Formosa, M. (2014). Four decades of universities of the third age: Past, present, future. Ageing and Society, 34(1), 42-66.

Foster, L. (2018). Active ageing, pensions and retirement in the UK. Journal of Population Ageing, 11(2), 117-132.

Furunes, T. F., Mykeltun, T. J., Solem, P. E., de Lange, A. H., Syse, A., Schaufeli, W. B., \& Ilmarinen, J. I. (2015). Late career decision-making: A qualitative panel study. Work, Aging and Retirement, 1(3), 284 295.

Genoe, M. R., Liechty, T., \& Marston, H. (2018). Retirement transitions among baby boomers: Findings from an online qualitative stud. Canadian Journal on Aging, 37(4), 450-463.

Gettings, P. E. (2018). Discourses of retirement in the United States. Work, Aging and Retirement, 4(4), 315329. https://doi.org/10.1093/workar/way008.

Hall, S. \& Keohane, N. (2016). Preparing for later life: working longer and saving more. Joseph Rowntree Foundation. Retrieved from https://www.jrf.org.uk/report/preparing-later-life-working-longer-andsaving-more. Accessed 14 May 2020.

Hamilton, M. and Hamilton, C. (2006). Rich Boomer, Poor Boomer: Retirement prospects for the not-so-lucky generation. The Australia institute. University of Sydney. Accessible pdf https://www.researchgate.net/ profile/Myra_Hamilton/publication/237531855_Rich_Boomer_Poor_Boomer/links/ 004635320d418dcadd000000/Rich-Boomer-Poor-Boomer.pdf. Accessed 14 May 2020.

Heinz, W. (2017) Conceptual foundations of qualitative life course research, Sociologia, Revista da Faculdade de Letras da Universidade do Porto, Número Temático - Famílias e Curso de Vida. Potencialidades, limites e desafios metodológicos, pp. 20-37. https://doi.org/10.21747/0872-3419/tema3. Accessed 14 May 2020.

Heinz, W., \& Kruger, H. (2001). Life course: Innovations and challenges for social research. Current Sociology, 49(2), 29-45.

Heinz, W. H., Huinink, J., \& Weymann, A. (Eds). (2009.) The Life Course Reader: Individuals and Societies Across Time (Frankfurt, Campus). Available at https://beckassets.blob.core.windows.net/product/ readingsample/493922/9783593388052_excerpt_001.pdf. Accessed 10 June 2019.

Henretta, J. (2003). The life-course perspective on work and retirement. In R. Settersten (Ed.), Invitation to the life course (pp. 85-106). London: Routledge.

Heraty, N., \& McCarthy, J. (2015). Unearthing psychological predictors of financial planning for retirement among late career older workers: Do self-perceptions of aging matter? Work, Aging and Retirement, 1(3), 274-283.

Hockey, J., \& James, A. (2003). Social identities across the life course. Basingstoke: Palgrave MacMillan.

Hollstein, B. (2018). What autobiographical narratives tell us about the life course: Linking biographical and life course research. Advances in Life Course Research, 41, 100248. https://doi.org/10.1016/j.alcr.2018. 10.001 .

Johnson, K., \& Mutchler, J. (2014). The emergence of a positive gerontology: from disengagement to social involvement. The Gerontologist, 54(1), 93-100.

Karp, D. A. (1989). The social construction of retirement among professionals 50-60 years old. The Gerontologist, 29(6), 750-760.

Keogh, M., \& Roan, A. (2016). Exploring teachers' early-retirement decisions: A qualitative study. Work, Aging and Retirement, 2(4), 436-446.

Kojola, E., \& Moen, P. (2016). No more lock-step retirement: Boomers' shifting meanings of work and retirement. Journal of Aging Studies, 36, 59-70.

König, S., Lindwall, M., \& Johansson, B. (2019). Involuntary and delayed retirement as a possible health risk for lower educated retirees. Journal of Population Ageing, 12(4), 475-489.

Laslett, P. (1989). A fresh map of life: The emergence of the third age. London: Weidenfeld and Nicolson.

Leinonen, T., Martikainen, P., \& Myrskylae, M. (2018). Working life and retirement expectancies at age 50 by social class: period and cohort trends and projections for Finland. The Journals of Gerontology. Series B, Psychological Sciences and Social Sciences, 73, 302-313.

Liebow, E. (1967). Tally's Corner. A study of Negro Street Corner Men. Boston: Little, Brown. 
Moen, P., Sweet, S., \& Swisher, R. (2005). Embedded career clocks: the case or retirement planning. Advances in Life Course Research, 9, 237-265.

Moffatt, S., \& Heaven, B. (2017). "Planning for uncertainty": narrative on retirement transition experiences. Ageing and Society, 37(5), 879-898.

Nolan, A., \& Barrett, A. (2019). Working beyond age 65 in Ireland. Journal of Population Ageing, 12(3), 299-326. https://doi.org/10.1007/s12062-019-09249-3.

Ponomarenko, V., Leiest, A. K., \& Chauvel, L. (2019). Increases in wellbeing in the transition to retirement for the unemployed: catching up with formerly employed persons. Ageing and Society, 39(2), 254-276.

Principi, A., Santini, S., \& Socci, M. (2018). Retirement plans and active ageing: perspectives in three countries. Ageing and Society, 38(1), 58-82.

Scales, J., \& Scase, R. (2000). Fit and Fifty. Swindon: Economic and Social Research Council.

Schmidt-Hertha, B., \& Rees, S.-L. (2017). Transitions to retirement - Learning to redesign one's lifestyle. Research on Ageing and Social Policy, 591, 32-56. https://doi.org/10.4471/rasp.2017.2426.

Schutz, A. (1970). On phenomenology and social relations. In H. Wagner (Ed.), Selected writings. Chicago: University of Chicago Press.

Settersten, R. (Ed.). (2003). Invitation to the life course: towards new understandings of later life. Amityville: Baywood Publishing.

Sheppard, F. H., \& Stanford, D. (2019). Women's perceptions of retirement. Journal of Gerontological Nursing, 45(4), 31-39.

Sherry, A., Tomlinson, J. M., Loe, M., Johnston, K., \& Feeney, B. C. (2017). Apprehensive about retirement: women, life transitions, and relationships. Journal of Women \& Aging, 29(2), 173-184.

Smeaton, D., Barnes, H., \& Vegeris, S. (2017). Does retirement offer a 'window of opportunity' for healthy lifestyle change? Views from workers on the cusp of retirement. Journal of Aging and Health, 29(1), 2544.

Solem, P. E., Syse, A., \& Furunes, T. (2016). To leave or not to leave: retirement intentions and retirement behavior. Ageing and Society, 36(2), 259-281.

Stafford, M., Cooper, R., Cadar, D., Murray, E., Richards, M., Stansfeld, S., Zaninotto, P., Head, J., \& Kuh, D. (2017). Physical and cognitive capability in mid-adulthood as determinants of retirement and extended working life in a British cohort study. Scandinavian Journal of Work, Environment \& Health, 43(1), 1523.

Steiber, N., \& Kohli, M. (2017). You can't always get what you want: actual and preferred ages of retirement in Europe. Ageing and Society, 37(2), 352-385.

Swain, J. (2018). A Hybrid Approach to Thematic Analysis in Qualitative Research: Using a Practical Example: Sage Research Methods Cases. London: Sage. Online ISBN: 9781526435477. https://doi.org/ $10.4135 / 9781526435477$.

Taneva, S. K., Arnold, J., \& Nicolson, R. (2016). The Experience of Being an Older Worker in an Organization: A Qualitative Analysis. Work, Aging and Retirement, 2(4), 396-414.

Verd, J. M., \& López, M. (2011). The rewards of a qualitative approach to life-course research. The example of the effects of social protection policies on career paths. Qualitative Social Research, 12(3), Art 15. Available at http://www.qualitative-research.net/index.php/fqs/article/view/1753/3259. Accessed 2 Dec 2020.

Vickerstaff, S., \& Cox, J. (2005). Retirement and risk: the individualisation of retirement experiences. The Sociological Review, 53(1), 77-95.

Zaidi, A., \& Howse, K. (2017). The policy discourse of active ageing: some reflections. Journal of Population Ageing, 10(1), 1-10.

Publisher's Note Springer Nature remains neutral with regard to jurisdictional claims in published maps and institutional affiliations. 